\title{
THE IMPLEMENTABILITY OF LOW CARBON CITIES IN THAILAND: A CASE OF HAT YAI CITY MUNICIPALITY
}

\author{
BOONSOM THITICHAYA AND CHOOSUK CHANISADA*
}

Faculty of Environmental Management, Prince of Songkla University, Hat Yai, Songkhla, Thailand..

*Corresponding author: chanisada.c@psu.ac.th

Submitted final draft: 15 August $2020 \quad$ Accepted: 23 September $2020 \quad$ http://doi.org/10.46754/jssm.2021.07.015

\begin{abstract}
This study aimed to describe the importance of low carbon policies and address strategies to promote community participation in implementing low carbon cities. Hat Yai City Municipality was observed as a case study on policy and participation. Although Hat Yai is an important economic city in Southern Thailand, it is prone to climate change threats and impacts. The study employed a qualitative design. Primary and secondary data were collected from documents, semi-structured interviews, focus group discussions, and participant observations. Thirty-seven key informants comprising 7 policy representatives of Hat Yai City Municipality, 20 stakeholders in low-carbon model communities, 4 private sector members, 2 media workers, 2 NGO members, and 2 civil society representatives were involved. Through content analysis and data triangulation, the results revealed key influencing factors of low carbon city implementation. The results revealed that the success of low carbon cities depends on the three P-S-P factors. The initial letter P refers to policies at the national and local levels. The following letterS refers to stakeholders who should be fostered on networking and cooperation. The final letter P refers to participation, which should be encouraged through context-based promotion of learning, whereas a cooperation network should be expanded to reach all stakeholders in society.
\end{abstract}

Keywords: Low carbon city, policy, participation, communities, Hat Yai City Municipality.

\section{Introduction}

Policies were formulated as implementational guidelines for projects and activities to ensure the success of the missions and they were widely applied in the work in relevant agencies, especially among the government agencies for public administration and addressing problems in the society, which stakeholders across sectors encountered. Nevertheless, there could be many types of problems, including environmental ones. Many countries employed policy strategies and tools to manage their environmental problems through operating regulations as legal measures and controls, incentives as economic measures, and awareness cultivation as motivation. To achieve voluntary cooperation in solving the emerged problems (Opschoor \& Pearce, 1991) and to follow key international approaches against climate change, policies on low-carbon society were established to tackle problems and mitigate impacts (IPCC, 2014). The concept of low-carbon cities is crucial for city administration, which requires the administration to use measures and activities to foster urban society's public participation in the reduction of greenhouse gas emissions as $70 \%$ of these emissions are generated in urban areas (Jabareen, 2015).

The movement for low carbon cities has substantially received attention and cooperation from many countries around the world, including developed and developing countries, which have and have not ratified the Kyoto Protocol. Many developed countries and members of the Annex-I parties to the Kyoto Protocol (e.g., China, Japan, United Kingdom, Canada, America, Germany, and other European Union members) have already implemented schemes of low carbon cities using multi-actor mechanisms that form robust participation among public sectors, private entities, civil societies, and local communities (Van der Heijden, 2016). Currently, low carbon cities are widespread. Many of these cities are in 27 European Union nations (daGraçaCarvalho et al., 2011)to ensure that $20 \%$ of final energy 
consumption is met with renewable sources, and to raise energy efficiency by $20 \%$. This strategy is based on the scientific consensus drawn by the International Panel for Climate Change, and implements the EU political strategy to limit the anthropogenic temperature rise to no more than $2{ }^{\circ} \mathrm{C}$. A Directive for the geological storage of $\mathrm{CO} 2$ is another integral part of the package. This should enable the development and subsequent deployment of zero emission power plants. From a research and technology perspective, the Strategic Energy Technology Plan (SET-Plan. Furthermore, there are approximately 1,050 cities in the United States, 40 cities in India, 100 cities in China, and 83 cities in Japan (Tan et al., 2017). The data implicated that low carbon cities are viable and achievable as the concept has evidently been employed as anti-climatechange strategies in various countries.

Although Thailand is not listed in the Kyoto Protocol's Annex I Parties, it still shares mutual obligations with the international community to work in cooperation to reduce greenhouse gas emissions. Via INDC (Intended National Determined Contribution), the country stood by its intention for the reduction of greenhouse gases by promising to activate countermeasures against climate change by 2020 with the target of achieving 20-25\% Intended National Determined Contribution (INDC) by 2040 following the guidelines of the Sustainable Development Goals (SDGs) (Bhundej, 2015). Nevertheless, figures showed that Thailand's trend on emissions has contrarily been on a constant rise. In 2000, 220.72 million tons of carbon dioxide equivalent $\left(\mathrm{MtCO}_{2}\right.$-eq) was emitted, and in 2011, 305.52 $\mathrm{MtCO}_{2}$-eq was emitted. The figures indicate an increase of almost $85 \mathrm{MtCO}_{2}$-eq in a decade. Furthermore, estimates illustrated that greenhouse gas emissions could double in 2020 and triple in 2040 (Chanjirawuttikul, 2012)

Hence, Thailand has the policy to incorporate the guidelines for low-carbon urban development in its Eleventh (2012-2016) and Twelfth (2017-2021) National Economic and Social Development Plans. In 2011, the
National Municipal League of Thailand began implementing the first scheme for low carbon cities with the code name "Thai Municipalities for Low Carbon Cities" after receiving 90\% of the financial support from the European Union (EU). The scheme offered local administrative organisations, including town and city municipalities across the country, an opportunity to apply for the programme, where the selected bodies were to carry out operations towards becoming a low carbon city following the given guidelines. Consequently, 167 municipalities submitted the applications, and 15 were chosen as models for low carbon cities. In terms of Southern Thailand, Hat Yai City Municipality participated in this scheme for low carbon cities. It was selected as one of the model cities by the National Municipal League of Thailand. To comply with the programme, four strategies from the low carbon city guidelines were implemented: City of Trees, City of Waste Minimisation, City of Energy Efficiency, and City of Sustainable Consumption. The municipality is an urban community that houses a large and condensed population, holds risks for climate change impacts, and shares a flood-prone basin. City activities accelerate greenhouse gas emissions (e.g., waste, air, and water pollutions and energy consumption). Since most city residents value occupations for their economic stability, the development of low carbon cities could pose a direct challenge to urban environments and their behaviours, and this notion is inevitably a challenge for the city administration.

Literature review found that the number of available qualitative studies on climate change mitigation and participation policy was rather limited, especially ones on developmental strategies for low carbon cities in the context of developing countries. The researcher reviewed and analysed the literature on urban city samples in five developing countries. Firstly, in Bandung, Indonesia, there was a study on carbon-emission measurements before and after the transition to LED lamps, which plotted maps for low carbon emissions in six urban development areas. The study objectively and scientifically compared 
emissions of carbon dioxide (Yusup, Melda \& Maman, 2020). Secondly, a study was conducted on Iskandar in the south of the Malaysian peninsula for low-carbon city planning through sustainable development measures. Efficiency in massive energy consumption was investigated using low-carbon and technologically produced energy sources. Consumption patterns and behaviours that emit low greenhouse gases were also promoted. Hence, the study incorporated low-carbon concepts and visions, resorted to strategies that reduce carbon emissions, and offered beneficial quantitative insights for lowcarbon urban development (Ho, Matsuoka, Simson \& Gomi, 2013). Thirdly, Phnom Penh and Siem Reap in Cambodia were studied in conjunction with the plan to reduce greenhouse gases. A scientific investigation was conducted to determine the origin of the cities' greenhouse gas emissions and discovered some quantitative data suggesting that the primary greenhouse gas emissions were from diesel engines (Sothea \& Oanh, 2019). Fourthly, there was an attempt in Hanoi, Vietnam, to use technology to save energy, generate economic benefits, and reduce greenhouse gas emissions through the evaluation of the implementation of remote sensing technology. (Phap, Huong, Hanh, Duy $\&$ Binh, 2020). Finally, in Thailand, there have been ongoing quantitative studies and the recent one is the use of a quantitative model that coupled weather forecasting with chemistry to simulate carbon concentrations in Thailand in 2017 with the goal of assessing the contributions of local emissions and regional transportation of Thailand. (Xing, Li, Pongpiachan \& Wang, 2020).

Apparently, the above urban area case studies focused on quantitative investigations for the development of mega-infrastructures to achieve comprehensive reduction results of greenhouse gas emissions. Prioritising macro modifications, the studies proposed no practical mechanisms for a local administration, e.g., urban and non-urban municipal units, which are a fundamental front that can have an impact on the reduction of greenhouse gas emissions at the city level. Therefore, this study used Hat Yai City Municipality as a case study with the objectives of investigating the policies and operational participation in the scheme for low carbon cities, as well as identifying facilitating factors for and barriers against such schematic manoeuvres for low carbon operations in Thai administrative . On this note, the study aimed to answer the following research questions:

How vital is the low carbon policy to an implementation of a low carbon city?

What strategies could be employed to promote community participation in implementing a low carbon city?

What are the influencing factors in achieving a low carbon city?

The results of this study were projected to promote sustainable development in formulating low carbon city policies, offer operating guidelines for local participation and efficient low carbon operations, and shed light on the possibility for other communities in and out of Thailand to successfully achieve their low carbon cities.

\section{Theoretical Background}

\section{The Concept of Low Carbon City}

Low carbon city is a sustainable urbanisation ideology to limit carbon footprints at the city level through the decreased consumption of fossil fuel energy. The ideology adopts two conceptual frameworks, i.e., low carbon society and low carbon economy, in its collaboration between the public, private, and civil sectors. Ismaila \& Bununu (2019) and Mao, Ma, Wang \& Bian (2019) pointed out that low carbon cities arean essential urbanisation mission to establish environmentally-friendly societies that favor a simultaneous development of low carbon economy and environments. The implementation of low carbon cities comprised two vital mechanisms, i.e., absorption and emission. 


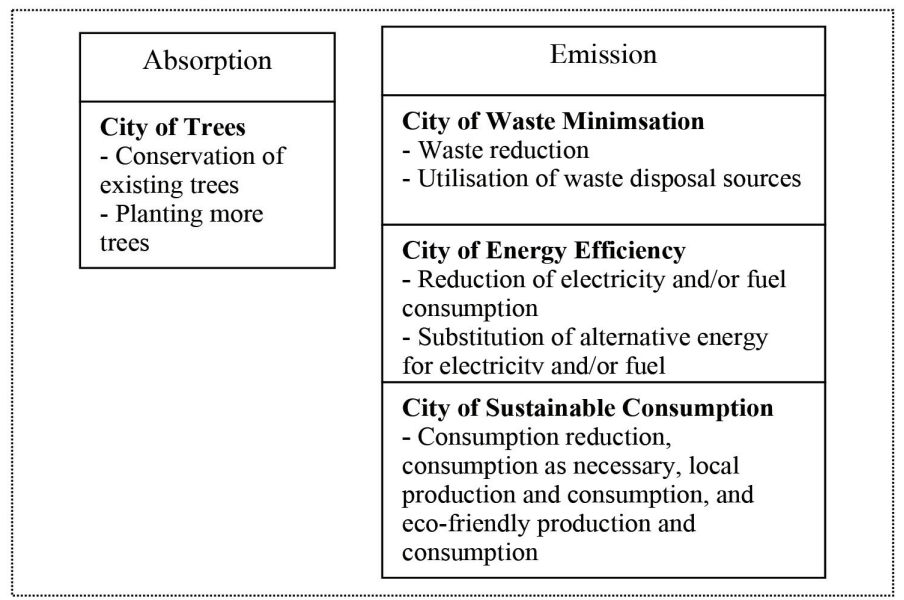

Figure 1: Guidelines for low carbon city operations

The implementing strategies for low carbon cities follow the Low Carbon Development Strategies (LCDS), which were broadly proposed by the Parties to UNFCCC to guide countries in their efforts of emission reductions, and a part of the strategies states that "all countries shall prepare Low Emission Development Strategies...nationally-driven and represent (ing) the aims and objectives of individual Parties in accordance with national circumstances and capacities" (Cancun Agreement) (Clapp, Briner \& Karousakis, 2010). In general, each country has to come up with a similar set of developmental strategies on low carbon cities to reduce activities that emit greenhouse gases and a course of action for carbon dioxide absorption. To decrease city emissions, the following measures are available: (1) City of Waste Minimisation (Lou et al, 2019) (2) City of Energy Efficiency (Leveaque et al., 2019) and (3) City of Sustainable Consumption (Baeumler, Ijjasz-Vasquez \& Mehndiratta, 2012) To increase carbon dioxide absorptions, City of Trees is also noteworthy. These aforementioned measures have already been implemented as measures in many policies and plans for low carbon cities, e.g., Low Carbon Transition Plan of the United Kingdom (Nuzir \& Dewancker, 2014), Zero Emission Urban Mobility in Japanese Cities, and Low-Carbon Development for Mexico (Johnson, Alatorre, Romo \& Liu, 2009).
Many countries showed an interest in sustainable urbanisation through this low carbon city approach in the most recent Asia-Pacific Forum, which was hosted by the Capital of in Hunan Province, Changsha, in China during October 16-18, 2019. The fourth edition of the Asia-Pacific Forum on Green Low-Carbon Development accommodated more than 600 policymakers and technology developers who participated in an active discussion on a theme called "Low Carbon Solutions for Our Green Future" as the forum aimed to determine a developmental growth path for low carbon and future development for Asia and the Pacific as the region is home to a significant number of the world's population. Carbon dioxide emissions within the area increased rapidly from a $25 \%$ ratio of the world in 1900 to $40 \%$ in 2012 . Also, this ratio is expected to reach $50 \%$ in 2030 . Since climate change might lead to significant economic losses in many countries in Asia and the Pacific, the discussed preventive strategies on low carbon are adequately vital for them to invest in and carry out (Neil, 2019).

Furthermore, a meeting that is known as ASEAN-China Cooperation on Energy Transition and Climate-resilient Development was held on August 28, 2019, in Bangkok with more than 100 representatives from Southeast Asia, and China has concluded that climate change is a mutual challenge and countries 
should confront it together. Through this joint effort, countries should transition from their developmental models from the reliance of fossil fuel with adverse effects on climate change to clean and renewable energy as well as transform their communities into low carbon societies (Thailand Greenhouse Gas Management Organisation (Public Organisation), 2019).

Nonetheless, essential success factors of strategic implementation for low carbon cities include urban policies and political will. Hence, leaders at the local and national levels should show commitment to sustainable city development and win public confidence by demonstrating that policy implementation is practically imminent (Persson\&Sjöstedt, 2012). So far, there are many examples of low carbon cities, both in developed and developing countries. To start of the low carbon implementation, policies were issued to ensure that stakeholders are mutually aware of problems, invite all sectors to formulate an operating plan, assign practical duties, and conduct follow-up assessments (Roberts et al., 2018). For instance, leaders of the five coastal cities of Portland in the United States grouped up and took action against climate change by announcing that their towns would lower emissions of greenhouse gases to the atmosphere by at least $80 \%$ by 2050 using a well laid-out policy and an action plan (Merritt, 2015).

In Asia, Rajkot of India is one of the cities that is prioritising low carbon achievements. The city leader implemented a mechanism through policies requiring Rajkot Municipal Corporation (RMC), the city's primary transportation service provider, to improve the city's public transportation system and increase city buses in service by 44\% from 2012 to 2015 . The mechanism aimed to encourage the public to reduce the personal use of motorised vehicles. Furthermore, the city offered automatic rickshaw services, provided public bike stands, and implemented mobile technology for the rickshaw services. Apparently, this low carbon mechanism was performed without national or state support. Instead, it was the work at the city level and a result of the firm determination of city authorities and a local third party (Nakano et al., 2017). Moving on to the two cities of Malaysia: Johor and Penang, an environmental policy on waste management and climate policy was mandated through a collaborative effort of the central and local governments. This network of cooperation, which involves the central government, has proven to produce operational efficiency. Both city leaders also showed their strong determination and political intent to bring the cities forward as low carbon cities (de Oliveira, 2019).

In Thailand, although the implementation of low carbon cities has only recently begun, there is already an example of a city with environmental changes and city-level reduction outcomes on greenhouse gas emissions. The city is Klaeng in Rayong Province, which is situated in the East of Thailand. The leader of Klaeng declared environmental policies to make Klaeng a low carbon city. Through hard work on policy and implementation, the city, which had been facing waste problems for the past ten years, could now enjoy efficient waste management. More river green areas and public spaces are provided. Energy consumption is reduced with tram services that transport the elderly to public parks for their exercises and give students a ride within the municipal area for free. Solar cells are employed to produce alternative energy, and household gas is produced through garbage fermentation. Moreover, local resources are managed through a green market that offers locals a city-area platform to trade products and an opportunity to stimulate the community's financial circulations (Isariyanon, 2016).

Therefore, the concept of low carbon city would not be successful if the low carbon policy lacks a fundamental component, which is a citylevel control of greenhouse gas absorptions and emissions through goals for carbon reduction and technological management

\section{Participation in Low Carbon City}

Participation is a backbone of low carbon city development as it demonstrates a transparent 


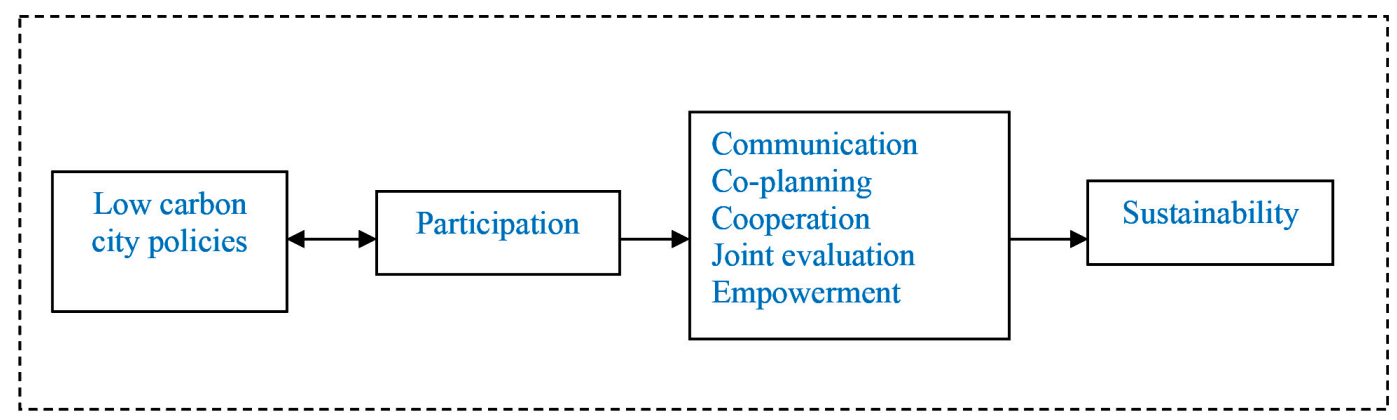

Figure 2: The key components in participatory policymaking for low carbon cities

administration. According to (Ramaswami et al., 2014), which is a study on Planning for Low Carbon Communities in US Cities, participation refers to support efforts that lead city members to gain knowledge, take part in planning, and jointly carry out missions towards a common goal. Ten Key Principles of Low Carbon Urbanisation by China Urban Sustainability Coalition (2015) emphasized participation as a critical factor in its Principle 9 by stating that participation is a transition from "city management" to "city governance" where low carbon cities are maintained with transparency through public participation with diverse stakeholders and participation is one of the key factors in urban development that could lead to sustainability.

The figure above describes the key components of participation that affect the implementation of low-carbon city policies. Simultaneously, the emergence of these policies is also vital to sustainable development as they foster bottom-up participation. A guideline for low carbon city development, a joint development by World Bank and DNV KEMA Energy \& Sustainability, was released after the launch of the low carbon city development in June 2012 at the United Nations Conference on Environment and Development or Rio de Janeiro Earth Summit in Brazil. Its Municipal Commitment section states that in the development of low carbon cities, a participation process should start with communication so that the general public and individuals in all sectors are aware of it (World Bank; DNV KEMA, 2014) since participation would become an essential step towards sustainability in project developments.(Glass \& Newig, 2019)

Examples of low carbon cities that incorporate a participation process as a primary mechanism for urban development include Denver and Broomfield in Colorado in the United States of America. Both cities created a participation model to educate city residents and offer them planning opportunities to enhance peoples' potentials within the communities (Ramaswami et al., 2011). European low carbon cities, such as the ones in the United Kingdom, France, Italy, Sweden, Portugal, Germany, Spain, Denmark, and the Netherlands, also employ the principles of community participation. These cities encourage community members from diverse professions to participate in urbandevelopment planning and opinion contribution to city policy formulation. These actions reflect transparency in operations. (O'Hara, 2013)

In the Asian contexts, studies on low carbon cities stated that successes could be achieved via participation. For instance, Melaka, a city in Malaysia, issued a climate adaptation policy with an emphasis on "good practices" and multi-sector climate governance. The city aims to become a green city and achieve carbon reduction by implementing a vertical administration using the central government and a horizontal administration using local mechanisms. A dual, collaborative, top-down, and bottom-up participation process was in place until the greenhouse gas reduction targets were reached. Eventually, Melaka was nominated as a model city for other Malaysian states with similar ecological and economic contexts (Zen et al., 2019). 
On the contrary, there are cases of cities where participation was missing, and the phenomena prevent governments from implementing set policies. The cases include Bangdung and Surabaya of Indonesia, where the local governments targeted to transform their urban transportation systems through an investment, known as Bus Rapid Transit (BRT). The policy is the result of cooperation between international development organisations and the central government with goals to support transportation policies, reduce traffic congestion, and reduce greenhouse gas emissions in low-income Asian (LIA) cities that are prone to climate change. However, the attempts were not successful as stakeholders (e.g., local communities, existing transport service providers, and concerned political parties) did not welcome the changes as the policies were perceived to have lacked a well-rounded participation mechanism (Wijaya et al., 2017).

In Thailand, the Klaeng City of Rayong remains successful as a model city for low carbon due to the presence of a participation process. Klaeng City collaborates with 16 communities in waste separation and has managed to reduce a significant amount of waste at the community level. Furthermore, (Isariyanon, 2016) another city with outstanding urban participation in transportation management is KhonKaen City Municipality, KhonKaen Province, which is located in Northeastern Thailand. The city employs a participation process known as public hearings. A review report for the construction of an LRT public transportation system in KhonKaen Province in November 2019 indicated that more than 1,000 people participated in its public hearing. Many questions were raised by the participants and answered by the respective responsible parties in management, traffic engineering, economics, and investment, as well as society and environment. The results of the public hearings were adapted as the development and management approach for the transportation system (Thaisaereenews, 2019).

Hence, the crucial components of participation include a process to stimulate information awareness, opportunities for social members to plan operations, carry out missions, evaluate outcomes, verify transparency, and propose ideas to policymakers which empowers participation through a bottom-up approach.

Based on the theoretical backgrounds containing the above key concepts on low carbon city policies and participation, the researcher constructed a conceptual framework as follows:

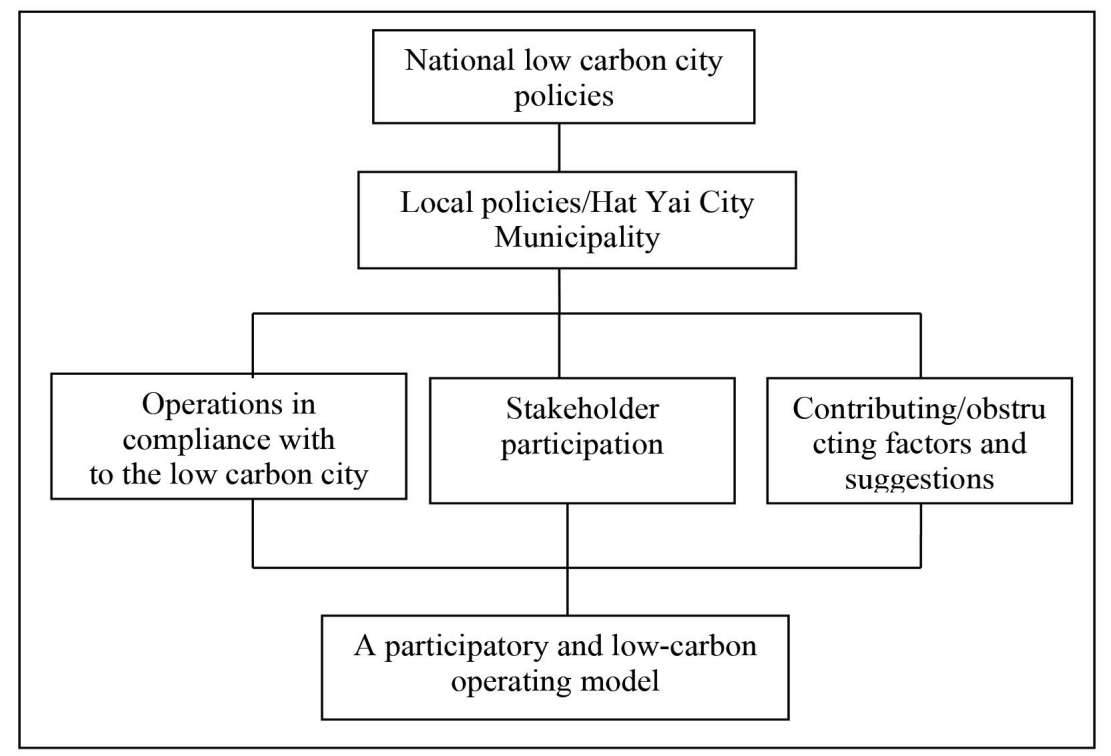

Figure 3: The conceptual framework 


\section{Materials and Methods}

\section{Research Context and Participant}

The spatial scope of this study is Hat Yai City Municipality in Mueang Hat Yai District, Songkhla Province. The area is located on a vast lowland sided by west, south, and east mountain ranges as well as a south-west land slope towards the Songkhla Lake. The municipality is as large as 21 square kilometres and home to a population of 158,432 populations (as of 2019) with an unregistered population of more than 200,000. It also annually accommodates an average of 1.5-2 million tourists. As a result, the city has a population density of 17,064 people per square kilometre.

Hat Yai City Municipality is situated in a foothills terrain and its socio-economic environment makes Hat Yai a central city with dense business and residential establishments. With these conditions, Hat Yai's natural elements deteriorate and the city loses its natural catchment areas and frequently suffers from devastating floods, e.g., in 1988, 2000, and 2010 as these disasters are associated with urban environments and climate change. The Asian Cities Climate Change Resilience Network (ACCCRN) forecasted the next 90 years of temperatures of Hat Yai using the A2 Scenario ${ }^{1}$ by splitting these years into four 30-year periods (e.g., Period 1 from 1980-2009 (base years), Period 2 from 2010-2039, Period 3 from 20402069, Period 2 from 2070-2099) and found that the average maximum summer temperatures tended to rise by $0.6,1.7$, and 2.9 degrees Celsius in 30, 60, and 90 years. Furthermore, average temperatures in rainy seasons tended to rise by $0.4,1.4$, and 2.7 degrees Celsius with a constantly increasing tendency. On this note, it is evident that Hat Yai is vulnerable to climate change impacts (Thailand Environment Institute, 2017).

This study employed a purposive sampling technique to include two sample groups to represent their population groups and involve in the interviews. The first group is the policy representatives from Hat Yai City Municipality, which included administrators who make policies and officials who implement them. The second group included the stakeholders representing the low-carbon communities, media workers, private-sector parties, members of NGOs, and members of the civil society sector. The table 1 contains these specifics.

\section{Research Instruments and Data Collection Procedures}

Primary and secondary data were collected. The secondary data were obtained from documents on the low carbon works of Hat Yai City Municipality, including the annual report of 2013-2015, the three-year local development plan of 2012-2014, and the yearly plan for municipal development of 2015-2017, the three municipal journals of 2013-2015, the report on city greenhouse gas emission data to support the implementation of low carbon city in 2012,the carbon footprint report of Hat Yai City Municipality in 2012, two reports on monthly meetings, and the guideline on leader and staff training for pilot municipalities of the Thai Municipality Project towards Low Carbon Cities. In addition, 43 studies on low carbon city development in developed and developing countries and 15 domestic and international websites were examined to generate basic and relevant information on low carbon city and environment policies.

The primary data were collected through the field and semi-structured interviews so that the specific data could be obtained as planned, i.e., opinions based on direct experiences of the key informants. The interviews of the policy group were conducted in the formal Thai language for 45-60 minutes. The key informants were interviewed individually on different occasions and locations. During the regular hours of public services, the interviews took place within the municipal office area, whereas during holidays, the interviews took place at the city's public gardens and coffee shops for a relaxed atmosphere. Furthermore, the interviews of the leaders and members of the four communities were conducted in the Southern dialect to 
Table 1: The key informants of the policy group and the stakeholder group

\begin{tabular}{cll}
\hline Organisations/Agencies/Communities & \multicolumn{1}{c}{ Individuals } & Quantity (persons) \\
\hline Hat Yai City Municipality & $\begin{array}{l}\text { - Three administrators and an official } \\
\text { from each bureau/division }\end{array}$ & 7 \\
\hline $\begin{array}{c}\text { Supap Onwan Community } \\
\text { (A low carbon community) }\end{array}$ & $\begin{array}{l}\text { - One community leader } \\
\text { - Five community members }\end{array}$ & 5 \\
\hline $\begin{array}{c}\text { Hat Yai Nai Temple Community } \\
\text { (A low carbon community) }\end{array}$ & $\begin{array}{l}\text { - One community leader } \\
\text { - Five community members }\end{array}$ & 5 \\
\hline Rim Kuan Community & - One community leader & 5 \\
\hline (A low carbon community) & - Five community members & 5 \\
\hline Pom Hok Community & - One community leader & \\
\hline (A low carbon community) & - Five community members & 2 \\
\hline Mass media & - One local-newspaper representative & 4 \\
\hline Private sector & - One local-radio representative & \\
\hline NGOs & - Two local business owners & 2 \\
\hline Civil society & - Two business-branch owners & 37 \\
\hline
\end{tabular}

establish a sense of trust and offer a less stressful conversational atmosphere. The conducts took place in garden courtyards of the community leaders and houses of members of the Urban Vegetable Garden. The participant observations were conducted on three occasions during various activities and meetings on low carbon missions that involved both representatives from the administrative and community sides. Observation data were collected from behaviours and expressions that were committed when opinions were raised, e.g., when the key informants showed a sign of acceptance or rejection. The three occasions included monthly meetings between administrative representatives and community leaders, field meetings in the communities by administrators, officials, community leaders, and community members, as well as a presentation activity hosted to welcome evaluators on environmentally sustainable cities in community offices. The focus group discussions were conducted twice.
Specifically, the first focus group was held in a meeting room at the Hat Yai City Municipality Office and the second session was organised in the city center garden.

Nevertheless, the interview questions were predetermined and open-ended. Flexible responses were expected so that the informants had the opportunity to share ideas based on their participation experiences in three scopes including policy, participation, and facilitating or obstructing factors. Examples of the questions are as highlighted in the table 2.

The questions were administered in the focus groups by starting from general urban environmental issues, urban development activities to address the four strategies in the low carbon city guidelines, low carbon policies, and suggestions on participation promotion. Once the primary and secondary data were acquired, they were verified for reliability and accuracy using a data triangulation, and this was when 
Table 2: Example question scopes

\begin{tabular}{cl}
\hline $\begin{array}{c}\text { Key informant } \\
\text { representatives }\end{array}$ & \multicolumn{1}{c}{ Question scopes } \\
\hline $\begin{array}{c}\text { Municipal policy } \\
\text { representatives }\end{array}$ & - What are the strategies for environmental development? \\
& - What motivations are behind the policy formulation? \\
& - How are low-carbon cities important to urban development? \\
& - How has participation been promoted in low carbon city operations? \\
& - What projects/activities are there to support low carbon operations? \\
& - What factors are vital in urban development and what are the obstacles? \\
\hline Community & - What are your thoughts on urban development policies, especially \\
environmental development? & - How well do you understand climate change and low-carbon cities? \\
& - In what environmental aspects have you participated with the municipality? \\
& - What are the activities that you have done to promote low carbon city \\
& operations? \\
& - What are the problems and obstacles in working with the municipality?
\end{tabular}

the data from the documents, the observations, and the interviews were compared (Bekhet \& Zauszniewski, 2012) and the resulting data were duplicated and saturated. For instance, the presented data were coded from the results, which are already a part of the data that is already saturated. Hence, the researchers analysed them further in the next sequence.

\section{Data Analysis Procedures}

The data were collected from a review of relevant literature and interviews. Subsequently, they were analysed with content analysis to draw an inductive conclusion. This analytical method is widely accepted as a research technique for qualitative studies with a capacity to describe contents in objective and quantitative data. Furthermore, where they are clearly and systematically presented through distinct message characteristics (Eichler\& Schwarz, 2019).

Via content analysis, the data contents derived from relevant literature and interviews were grouped into main topics (i.e., policy, participation, and implementation approaches for low carbon cities). Firstly, the subtopics on policy were policymakers, concepts, and policy-based practices. Secondly, the subtopics on participation included participants and participatory roles and activities. Thirdly, the subtopics on low carbon implementations were operating methods for each approach and influencing factors that generate operational results. The interview contents were managed in procedures from transcriptions, English translations, thorough reviews, and topicbased data sorting. Subsequently, the data were retrieved and recompiled into new narrations. Then, the data were analysed using three primary theories, including policy, participation, and low carbon city concepts. After the results were compared with theories to see if they offer consistencies, they were written in detail as descriptive notes.

\section{Findings and Discussion}

The results are presented in three parts to answer the research questions on how vital the low carbon policy is to an implementation of a low carbon city, what strategies could be employed to promote community participation in an implementation of a low carbon city and what influencing factors of a low carbon city implementation are. This study essentially examined Hat Yai City Municipality's participatory operating structure on low carbon cities and revealed the following results. 


\section{The Low Carbon City Policy of Hat Yai City Municipality}

According to the guideline on leader and staff training for pilot municipalities of the Thai Municipality Project towards Low Carbon Cities (2012), the low carbon city policy emerged and was put into practices when Hat Yai City Municipality participated in the Thai Municipality Project towards Low Carbon Cities during 2011-2015 with the National Municipal League of Thailand. The project by the National Municipal League of Thailand 90\% was funded by the European Union (EU) was designed to foster participating municipalities in their low carbon city implementations through four strategies including 1) City of Trees by preserving existing trees and adding more of them along with green areas, 2) City of Waste Minimisation by tackling root causes through pre-disposal waste minimization (e.g., garbage and wastewater) and solving immediate problems through wastewater treatment or waste re-utilisation at waste disposal/treatment facilities, 3) City of Energy Efficiency by reducing the use of energy and fuel and substituting alternative energy for electricity and fuel, and 4) City of Sustainable Consumption by reducing unnecessary consumption, promoting the consumption of local or nearby, and fostering the use of environmentally friendly products and services.

More into the specifics, the administrator of Hat Yai City Municipality provided insights during the interviews on the decision-making and the adoption of the guidelines for low carbon cities as part of the urban development policies in the local development plan by stating that:

"We see that the low carbon city approach is what we have already partially undertaken. Hence, participating in the Low Carbon City Project is in line with what we do. So, we just need to integrate the low carbon approaches into various strategies of the local development plan."

(A Hat Yai City Municipality administrator, interviewed on January 23, 2018)
The said confirmation is consistent with the data from the three-year local development plan (2012-2014) as the document contains information that indicates that the implementation guidelines for low carbon cities were integrated into the municipality's local development plan of 2012-2014. More specifically, "City of Trees" was mentioned in the plan for natural resources and environment development, whereas "City of Waste Minimisation" and "City of Sustainable Consumption" were integrated into the social development plan and "City of Energy Efficiency" in the infrastructure development plan.

After the administrator of Hat Yai City Municipality has issued a low carbon city policy and included the low carbon city guidelines in the annual local development plan, a task force on policy implementation was established. The agency further determined that the operational mechanism would include bureaus and divisions in a task force for the sustainable environmental city. In terms of responsibilities, the Bureau of Mechanics was responsible for the City of Trees and City of Energy Efficiency, the Bureau of Public Health and Environment was responsible for the City of Waste Minimisation, and the Division of Social Welfare was responsible for the City of Sustainable Consumption. In general, the policy required these offices to operate in two parts: reduce greenhouse gas emissions within offices and buildings of Hat Yai City Municipality, continue with the existing and relevant tasks, and implement the low carbon city guidelines at the community level. An official in charge of the low carbon mission stated during an interview that:

"The municipality wants to see the low carbon city policy implemented for the entire city in a big picture. However, our city is a business center with a large number of people. So, we first started in our agency at the office, and then we extend it to the communities that are ready for it first. It is easier this way than doing it to the whole city at once."(A municipal official, interviewed on January 23, 2018) 
The interview demonstrated that although there were as many as four strategies for low carbon cities, the initial implementation was practised only within the agency and select communities. As a result, the actions would not create a significant impact on reducing greenhouse gas emissions for the entire city system. When considering the policy implementation procedures, the resulting low carbon city policies were not problem-based (Birkland, 2020). Despite the fact that both the government and the general public did work together to identify problems, generate a working plan, coordinate on a cooperative mission, and jointly evaluate performances, the policies could be issued when the local administration body through the blessing of the leader found that it was appropriate to use the low carbon city approaches as a tool to support environmental development and solve city's problems to mitigate climate change risks. In the contexts of Thailand, Thai public administration, roles, and leadership are extremely necessary. As stated in the interview by a project coordinator of the Thai Municipality Project towards Low Carbon Cities at the National Municipal League of Thailand:

"In Thailand, whatever you do, it starts with a leader. The low carbon city project is no exception. The head must move, so the tail can wiggle. Hat Yai is considered lucky that the leader did not oppose the movement and gave support, although the leader who supported was a vice mayor who decided to play the main role in this event."

(A project coordinator of the National Municipal League of Thailand, interviewed on February 1, 2018)

Based on this interview input, it was evident that Hat Yai City Municipality did not operate in a process that is consistent with the policy formulation procedures. On the contrary, it was their leaders who supported the cause by adopting external strategies as they were convinced by the National Municipal League of Thailand that problems were imminent and that they were possible approaches to counteract with the dilemma, including the low carbon city scheme. This phenomenon reflected the good-will commitment for policymaking on the administrative end. Nonetheless, with this end alone, the commitment would never reach its peak as dedicated policies on "low carbon cities" remained missing. Furthermore, when analysing the reports on the reduction results of greenhouse gases, it was noticeable that the contents were not chronologically presented. In other words, the result of the pre- and postoperation timeline was missing. Also, there was no projected visualization for the city's future. Hence, the presented policy performance sent a message that these operations were designed for short-term executions reflecting the fact that the policy formulation was no match with the public policy procedures. With this missing link, it would be unlikely that the urban residents would be adequately empowered to dictate their future in the city and autonomously drive the low carbon movement in the long run.

Hence, the first question on how vital the low carbon policy is whether an implementation of a low carbon city could be answered as follows. Policies are essential for operations to meet targets and achieve the reduction of the city's greenhouse gases and the reason why they are vital is reflected through the factors that are behind the emergence of these policies. When considering the procedures for the emergence of public policies for environmental management (Thomas, 2007), it was found that the starting point was not the identification or the scoping of problems which became a common "goals and actions" of the city. The policies were scoped through policy decisions and publicly announced within the organisations and only the operating networks were aware of the information. On policy implementation, monitoring, and evaluation, the organisations and the networks only generated internal reports which were not made public. Hence, these reports were not utilised for further performance expansion, improvement, or redesigns. Contrarily, since the actions took place as the administrators adopted external ideas, the implementation of Hat Yai 
City Municipality's low carbon city policies was less impactful to drive significant changes in the low-carbon urbanisation. The reason is that, as the public did not demand policy solutions, these policies were not formulated based on how the public perception of climate change issues and impacts. Policy-originating causes are vital to the drive for social changes.

\section{Participation in Community Operations for Low Carbon}

Relevant studies on results of community participation in operations for "low carbon communities" emphasised participation as fundamental to urban development as it reflects management transparency (Mees et al., 2019) but government roles may need to shift: from a regulating and steering government towards a more collaborative and responsive government that enables and facilitates community initiatives that are self-governed by citizens. However, we lack a conceptual understanding of such new government roles, as well as empirical insights into how local governments participate in citizens' initiatives and how they take up such new roles. In this paper, a "ladder of government participation" is introduced, which is used to explore the roles of local governments in citizens' initiatives for climate change adaptation in the Netherlands. The results show that local governments are slowly but gradually shifting towards more networking, stimulating, and facilitating roles. Key concerns of local practitioners are (a. Hence, a participation process should begin with information disclosures so that stakeholders in all sectors are aware of the facts. As documented, many developmental efforts for low carbon cities that made use of participation, starting with the community level, have produced desirably tangible outcomes. Based on the notion, Hat Yai City Municipality also gave its communities the opportunity to participate in the low carbon operations. Evidently, four potential communities were selected by the municipality based on leadership readiness and involvement of community members in activities that favor the low carbon efforts. A community representative stated during an interview about the participation in low carbon missions with Hat Yai City Municipality that:

"Growing vegetables for self-consumption is something we are already doing. As for waste separation, we use the waste from food and vegetables to produce fertiliser. We often did the recycling, but not regularly, but when the municipality gave us the knowledge, we are doing it more systematically."

(A representative of the community leaders, interviewed on April 5, 2018)

The interview data demonstrated that the municipality encouraged participation through the introductions of news and knowledge to the communities with anticipation that such actions would bring about cooperation and practices. The four participating communities, out of the total 103 , were with different numbers of households and households participating in the low carbon scheme. SupapOnwan Community is to the east with 350 households and 20 participating households (5.71\%). Rim Kuan Community is to the west with 1,349 households and 46 participating households (3.4\%). Hat Yai Nai Temple Community is a flood-prone area at the central and near Utapao Canal with 670 households and 20 participating households (2.98\%). PomHok Community is a congested area located in the city center near the railway line with 478 households and 150 participating households (31.38\%). The individual participation rate of the four communities contributed $8.28 \%$ engagement, and as only four out of the total 103 communities were involved the community participation rate is $4.12 \%$.

Based on the results in the 2012 carbon footprint report of Hat Yai City Municipality and the interview data, City of Waste Minimisation was the most participated strategy through the separation of household organic and recyclable waste. Contrarily, other strategies were received minimal operational participation due to the city contexts being highly urbanised, forcing city residents to focus their lives more on economic sustainability. This is not to mention 
that different communities were with varying types of members and levels of readiness. In this case, factors that would encourage and maintain constant paces of participation were the proactive and consistent pushes from the responsible municipal officials. An official in charge of waste management illustrated in an interview that:

"Each community has different levels of readiness and commitment. Our municipal officials made a request on behalf of the municipality for participation, and we did not force them to do anything. The process was voluntary. So, the communities did what they thought was best with their expertise. At the same time, productivity depends on how proactive the municipal officials could be. For instance, in the case of waste management, we followed up and pushed harder by asking how the communities had done so far. With that consistency, we were able to see results."

(A municipal official in charge of waste management, interviewed on February 7 , 2018)

From the said opinion, phenomena reflected the fact that the participation of the four communities did not come from the needs of their members. Instead, it emerged out of information awareness and operational incentivsation. Based on compiled data from monthly meeting reports during 2012, the performances on the four strategies for low carbon cities are as follows:

\section{City of Trees}

In the attempts to preserve existing trees, plant more, and add more green spaces in the areas of the four communities, results revealed that SupapOnwan Community was the only community with larger trees as it the community leaders' land is large enough to grow 23 trees. Since other communities are with crowded dwellings and without spaces for large trees, only decorative flowers, ornamental plants, and vegetables could be planted in smaller spaces or pots. To plant more trees and expand green spaces in other areas, the Bureau of Mechanics, Hat Yai City Municipality, was the body to carry out the mission. The bureau recorded the amount and type of plants and held some planting activities at city parks by involving the community leaders and members.

\section{City of Waste Minimisation}

Averagely, all four communities separated 2,348.23 kilograms of organic waste per year per community. The organic waste was used to manufacture bio-fertiliser for household use and retailing. Averagely, the communities separated 4,437.5 kilograms of recyclable waste per year per community using community leaders' houses as the trade centers of the waste. Furthermore, some houses of the community leaders were chosen to establish learning centers on waste management for members within the communities and from other communities to visit and share the learning.

\section{City of Energy Efficiency}

The four communities reduced their energy consumption through a similar measure, which was the effort to reduce the use of electricity in houses by referencing the monthly expenses as indicators. Results indicated that the reduction efforts were not significant, with an average reduction per household of no less than $30 \mathrm{baht} /$ month (from the average range of electricity cost of 200-600 baht/month). For the fuelconsumption reduction, it was found that there were approximately ten members in the Hat YaiNai Temple Community who tried to ride bicycles in their daily lives and a household at the Rim Kuan Community who tried to generate alternative energy for household use through animal-waste biogas. Nevertheless, such production was too little to match the consumption demand.

\section{City of Sustainable Consumption}

All four communities already had an ongoing activity to autonomously grow vegetables, and this household activity is consistent with 
the City of Sustainable Consumption strategy. Two of the communities, i.e., Supap Onwan Community and Rim Kuan Community, had adequate spaces for the community leaders to be used as vegetable plots. Consequently, after household consumption, excess products were sold, and the activity increased the average household income by $300-500 \mathrm{baht} / \mathrm{month}$. In contrast, Hat Yai Nai Temple Community and Pom Hok Community did have limitations as housing was highly condensed in the areas.
Hence, both communities struggled to allocate spaces for the crop growing. Nonetheless, community members attempted to design some farming solutions by planting vegetables on vertical shelves, and most of the produce was used for household consumption. The efforts helped reduce costs and waste from unnecessary trips of vegetable purchases at stores and markets. The low carbon city results through community participation are summarised in the following table.

Table 3: Summary of low-carbon city performance through community participation in 2017

\begin{tabular}{|c|c|c|c|c|c|}
\hline Communities & City of Trees & $\begin{array}{l}\text { City of Waste } \\
\text { Minimisation }\end{array}$ & $\begin{array}{c}\text { City of Energy } \\
\text { Efficiency }\end{array}$ & $\begin{array}{c}\text { City of } \\
\text { Sustainable } \\
\text { Consumption }\end{array}$ & $\begin{array}{l}\text { Performance on } \\
\text { greenhouse gas } \\
\text { reduction/absorption }\end{array}$ \\
\hline $\begin{array}{l}\text { Supap Onwan } \\
\text { Community } \\
\text { has } 350 \\
\text { households } \\
\text { whereas } 20 \\
\text { households } \\
(5.71 \%) \\
\text { participated. }\end{array}$ & $\begin{array}{l}\text { - Saving } 23 \\
\text { existing trees } \\
\text { - Participation } \\
\text { in the } \\
\text { planting } \\
\text { activities with } \\
\text { Hat Yai City } \\
\text { Municipality }\end{array}$ & $\begin{array}{l}\text { - Separation of } \\
1,730 \mathrm{~kg} / \text { year.of } \\
\text { organic waste on } \\
\text { average } \\
\text { - Separation of } \\
1,644.06 \mathrm{~kg} / \mathrm{year} \\
\text { of recyclable } \\
\text { waste on } \\
\text { average } \\
\text { - Community } \\
\text { Waste Learning } \\
\text { Center }\end{array}$ & $\begin{array}{l}-5-10 \% \\
\text { reduction of } \\
\text { household } \\
\text { electricity } \\
\text { consumption }\end{array}$ & $\begin{array}{l}\text { - Planting } \\
\text { vegetables in } \\
\text { vegetable plots } \\
\text { for consumption } \\
\text { - Generating } \\
300-500 \text { baht } \\
\text { of income per } \\
\text { household } \\
\text { on average } \\
\text { for growing } \\
\text { vegetables }\end{array}$ & $\begin{array}{l}\text { On the results of } \\
\text { greenhouse-gas reduction } \\
\text { from the separation of } \\
\text { organic waste at the } \\
\text { plants in making compost } \\
\text { and bio-fermented water, } \\
\text { Hat Yai City Municipality } \\
\text { combined the results of } \\
\text { these four communities } \\
\text { with operations in other } \\
\text { communities, making a } \\
\text { total of } 19 \text { target areas. }\end{array}$ \\
\hline $\begin{array}{l}\text { Hat YaiNai } \\
\text { Temple } \\
\text { Community has } \\
670 \text { households } \\
\text { whereas } 20 \\
\text { households } \\
(2.98 \%) \\
\text { participated. }\end{array}$ & $\begin{array}{l}\text { - Took part in } \\
\text { the planting } \\
\text { activities with } \\
\text { Hat Yai City } \\
\text { Municipality }\end{array}$ & $\begin{array}{l}\text { - Separation of } \\
2,348.23 \mathrm{~kg} / \\
\text { year.of organic } \\
\text { waste on } \\
\text { average } \\
\text { - Separation of } \\
2,018.5 \mathrm{~kg} / \mathrm{year} \\
\text { of recyclable } \\
\text { waste on } \\
\text { average } \\
\text { - Community } \\
\text { Waste Learning } \\
\text { Center }\end{array}$ & $\begin{array}{l}\text { - Reduction } \\
\text { of household } \\
\text { electricity } \\
\text { consumption } \\
\text { - Routine } \\
\text { cycling which } \\
\text { involved } 10 \\
\text { participants }\end{array}$ & $\begin{array}{l}\text { - Planting } \\
\text { vegetables } \\
\text { for household } \\
\text { consumption } \\
\text { Vertical vegetable } \\
\text { gardening }\end{array}$ & $\begin{array}{l}\text { Consequently, the overall } \\
\text { performance included: } \\
\text { - Average separation } \\
\text { of } 84,312.5 \mathrm{~kg} / \text { year of } \\
\text { recyclable waste } \\
\text { - } 131,447 \mathrm{~kg} / \text { year of } \\
\text { organic waste was used } \\
\text { to produce } 1,750 \mathrm{~kg} \text { of } \\
\text { compost and produce } 455 \\
\text { buckets of bio-fermented } \\
\text { water }\end{array}$ \\
\hline
\end{tabular}




\begin{tabular}{|c|c|c|c|c|c|}
\hline $\begin{array}{l}\text { Rim Kuan } \\
\text { Community } \\
1,349 \\
\text { households } 46 \\
\text { households } \\
(3.4 \%) \\
\text { participated. }\end{array}$ & $\begin{array}{l}\text { - Participation } \\
\text { in the } \\
\text { planting } \\
\text { activities with } \\
\text { Hat Yai City } \\
\text { Municipality }\end{array}$ & $\begin{array}{l}\text { - Separation of } \\
2,308.23 \mathrm{~kg} / \\
\text { year.of organic } \\
\text { waste on } \\
\text { average } \\
\text { - Separation of } \\
3,328.12 \mathrm{~kg} / \text { year } \\
\text { of recyclable } \\
\text { waste on } \\
\text { average }\end{array}$ & $\begin{array}{l}\text { - Reduction } \\
\text { of household } \\
\text { electricity } \\
\text { consumption } \\
\text { - Biogas } \\
\text { production } \\
\text { from manure }\end{array}$ & $\begin{array}{l}\text { - Planting } \\
\text { vegetables in } \\
\text { vegetable plots } \\
\text { for consumption } \\
\text { - Generating } \\
\text { 300-500 baht } \\
\text { of income per } \\
\text { household } \\
\text { on average } \\
\text { for growing } \\
\text { vegetables }\end{array}$ & $\begin{array}{l}\text { - } 1,566 \mathrm{~kg} \text { of hazardous } \\
\text { waste } \\
\text { which reduced } 417.6 \\
\text { tonCO } \mathrm{CO}_{2} / \text { year of } \\
\text { greenhouse gas } \\
(2017)\end{array}$ \\
\hline $\begin{array}{l}\text { Pom Hok } \\
\text { Community } \\
\text { has } 478 \\
\text { households } \\
\text { whereas } 150 \\
\text { households } \\
(31.38 \%) \\
\text { participated. }\end{array}$ & $\begin{array}{l}\text { - Participation } \\
\text { in the } \\
\text { planting } \\
\text { activities with } \\
\text { Hat Yai City } \\
\text { Municipality }\end{array}$ & $\begin{array}{l}\text { - Separation of } \\
6,918.26 \mathrm{~kg} / \\
\text { year.of organic } \\
\text { waste on } \\
\text { average } \\
\text { - Separation of } \\
4,437.5 \mathrm{~kg} / \text { year } \\
\text { of recyclable } \\
\text { waste on } \\
\text { average }\end{array}$ & $\begin{array}{l}\text { - Reduction } \\
\text { of household } \\
\text { electricity } \\
\text { consumption }\end{array}$ & $\begin{array}{l}\text { - Planting } \\
\text { vegetables } \\
\text { for household } \\
\text { consumption } \\
\text { Planting in pots in } \\
\text { front of houses }\end{array}$ & \\
\hline
\end{tabular}

The performance results of the four communities participating in the "low carbon communities" operations indicated that out of a total of 2,847 households, only 236 households $(8.28 \%)$ took part in the low carbon efforts. The most successful strategy was City of Waste Minimisation through initial waste minimisation. It was followed by "City of Sustainable Consumption" which the communities grew vegetables for consumption and reduction of household expenses, where households could also enjoy safe vegetables and boost incomes. "City of Trees" and "City of Energy Efficiency" yielded a less effective performance as city areas were short of lands for big trees, so green spaces were added at a minimal rate. Furthermore, on household energy reduction, the efforts only produced $5-10 \%$ reduction efficiency, whereas only a household produced biogas from animal waste at a quantity that was less than needed. Similarly, the efforts to reduce fuel traveling consumption were reflected only in a community where approximately ten members used bicycles on a daily basis. Based on the number of participating households in the communities, the operating circle for low carbon cities was still small. However, the data collected from the policy group, both from the administrators and the municipal officials, indicated a congruent reflection. As a city administrator elaborated during an interview:

"Although the participant in the low carbon communities of Hat Yai City Municipality was small in number, at least we were able to get some households to cooperate and that we consider a success. This city is large and full of diversity. Most of our residents focus on earning money for a living. Since environmental development was not their priority, when we could invite them to start to take part, we should count it as a productive start. As they intended to be role models, we hope that others in communities will observe them, learn from them, and follow the practices." (An Administrator of Hat Yai City Municipality, interviewed on July 4, 2018)

The Administrator of Hat Yai City Municipality seemed to be satisfied with the public participation. Even if it was small in number, the efforts reflected the fact that it is not easy for large cities to swiftly force behavioural changes. When the participation was less active, 
the reduction of greenhouse gas emissions would subsequently be less effective. Nevertheless, one could argue that doing something might be better than nothing. All in all, it would take time for Hat Yai City Municipality to reach quantifiable targets, and more proactive organisational mechanisms should be established to stimulate the chance of success. For instance, officials should work more closely with communities, form a "low carbon community network" for stakeholders to work forward together in a bigger picture as a city, and determine precisely what the low carbon city goals would be.

When comparing the above results, with related studies, it was found that the results were mostly in the same direction. For example, examined many low carbon cities in Europe and discovered that the cities were driven by community participation through the stimulation of knowledge, awareness, and understanding of the same problems at the community level. (O'Hara, 2013) As a result, stakeholders were actively engaged in joint problem-solving endeavors and worked together on self and household transformations to adopt low carbon behaviours. Their efforts were towards the same goal, which to reduce greenhouse gas emissions and mitigate impacts of climate change. Benites-Lazaro \& Mello-Théry(2019) the Clean Development Mechanism (CDM confirmed the importance of participation by referring to the United Nations Framework Convention on Climate Change (UNFCCC) and Clean Development Mechanism (CDM) that require local stakeholders to participate by sharing ideas and promote social equality, which is a vital factor for sustainable development. For cities with poor participation, low carbon implementation might fail or take longer to accomplish. According to Peng et al. (2018), who investigated participation behaviours of people in Wuhan, China on low carbon implementation, a local administrative unit initiated the project by encouraging community members to take part in a scheme on household energy-saving, effective use of resources, and recyclable waste separation. Results revealed that the community members were not so active in adopting low carbon behaviours nor paid attention to the communities' tree planting. The reason was that they were concerned about the resulting negative economic impacts. Hence, the study further suggested that a specific supportive measure or incentivisation should be used for the low carbon implementation to work.

The results were able to answer the second research question on how to foster community participation in the low carbon city effort. The answers are summarised as follows. The municipality should employ a communication process to stimulate awareness across all sectors. Such promotion of awareness should be conducted through an environmental education process with continuity. Citizens should be persuaded to realize that changing behaviours towards low-carbon society would, in return, enhance their quality of life. The municipality should employ organisational mechanisms through establishing groups and networks of cooperation across all areas. Special support and stimulus projects should be carried out to maintain the public relevance of low-carbon operations.

\section{Influencing Factors of Low Carbon City Operations in Hat Yai City Municipality}

Based on the results and in response to the research question on how to promote community participation towards low-carbon urbanisation, it was found that the community participation was most effective during the practice process as community members followed the practices and saw results in waste management, separation of recyclable waste, and separation of organic waste at Hat Yai City Municipality. Furthermore, these outcomes offered collective performance data on how much they were able to decrease greenhouse gas emissions at the city level. These practices and top-down participation was described in Tosun (1999) as resulting public participation that begins from an organisation which is not authentic and they are different from the bottom-up one which participation authentically arises from the needs of the people and it usually results in active participation and a 
contribution that would lead to effective actions (Tosun, 1999). This concept shares similar characteristics with a concept known as je jure and de facto. The researcher found that this concept was used in a comparison to promote understanding and to foster participation in environmental operations, which is as Leal and Marques (2019) described: laws are set as mandatory standards and involvement is legally mandatory. Participation could be voluntary or non-voluntary, but laws require participants to act accordingly. However, if the participation is voluntary, behavioural changes are cultivated through a public network with effective participation.

From such participation characteristics, when compared the participation in low-carbon city operations with cases of other cities, it was found that Kersty, Jo and Ruth (2014) did not indicate the importance of the participation process, but explained community cooperation is vital for being related to political interests. The study provided examples of actions to reduce greenhouse gas emissions in the community and they included diversification of community activities and innovative community involvement for joint local development based on the perceived benefits and values.

Furthermore, Peng, Wang, Zhao, and Wang (2018) investigated public participation in Chengyang District, Qingdao, China, and described the importance of firststep participation. The government should communicate and provide information to the public to promote understanding as well as emphasise practices by allowing the public to participate in energy conservation and emission reduction activities. The results of the study showed that the public understood that they received positive results from the practices. Hence, the government was able to broaden its participatory measures to cover more areas. The researcher perceives these low carbon city operations in China as beneficial and quickly responsive. The form of administration might have played a significant role in the phenomenon. Nevertheless, promoting participation in a democratic country such as the case of a city municipality in Odense, Netherlands, according to Mees, Uittenbroek, Hegger, and Driessen (2019), the municipality was able to sustainably alleviate public participation and participation from the civil society for low-carbon urban development. Planning was the focus of the effort and processes were implemented with citizens and members of civil society were positioned as formal and informal consultants or councilors. Since the consultation was conducted via the internet the mechanism was well responded by the public and received increased public support. As for the civil society sector, the municipality also offered opportunities for civilsociety members such as local media, inner-city business operators were invited to join in and express their views.

Therefore, to build community participation for low-carbon cities, local communities should be given importance, and stakeholders of all groups should be allowed to participate so that a low carbon city project could proceed. In the case of Hat Yai City Municipality and the participation of its stakeholders in the low carbon operations, it was found that the participation was quite incomplete when compared to other low-carbon cities. More specifically, the reason that the participation process was deemed incomplete is as communication was not yet able to reach all groups. On joint planning, not all concerned parties were invited to join and discuss. The only session they were involved in was when actions and practices were introduced to them and they were asked to follow. Although the community sector might benefit some tangible results from the effort, there were no clear measures and guidelines for other sectors. On joint monitoring and evaluation, it was found that no participation strategies were established to include all groups of stakeholders in the monitoring and evaluation.

This study discovered that influencing factors of low-carbon policies and participation for Hat Yai City Municipality were as follows. 


\section{Policy Guideline from Central Government}

According to the Eleventh and Twelfth National Economic and Social Development Plans, the Thai government has partnered with the international community in a collective effort to prevent and solve climate change problems. Included in the Eleventh National Economic and Social Development Plan (2012-2016) within the strategy for sustainable management of natural resources and environment, the greenhouse gas reduction policy states that:

"Developmental paradigms shall be adjusted to maneuver the national preparatory efforts towards a low carbon and environmentally friendly economy and society by restructuring the country's productions and consumption habits in preparation for low carbon and environmentally friendly economy to enhance energy efficiency in the transportation and logistics sectors, reduce greenhouse gases, develop environmentally friendly cities, emphasise urbanisation that combines cultures, societies, and ecosystems."

Political will from national leaders is another factor that can contribute to the success of Thailand's operations to reduce greenhouse gas emissions. The Thai Prime Minister participated in a high-level event on the entry into force of the Paris Agreement at the United Nations Headquarters, New York City, the United States in September 2015, and left a message at the forum. Part of the message was:

"Thailand is pleased to be a party that joined the Paris Agreement. It is one of the most important steps for Thailand. Thailand participated in the movement because we recognise that it is everyone's shared responsibility to save the world for our children. Hence, we must cooperate to limit the increase in global temperature and improve our adaptability. My presence signifies Thailand's steadfast determination to move towards a low carbon society" (UN Web TV, 2015)
Subsequently, the government included the eco-friendly growth strategy for sustainable development in the Twelfth National Economic and Social Development Plan (2017-2021), which suggests that reducing greenhouse gas emissions would remain a priority. The strategy indicates that:

"To support greenhouse gas emission reductions and increase adaptability to climate change, the government shall require the private sector, state enterprises, and local administrative organisations to collect and report relevant data on greenhouse gas emissions, foster knowledge, understanding, awareness, and participation among the general public and sector workers in a collective effort to fight the climate change."

In terms of future plans, Thailand was planning to reduce domestic greenhouse gas emissions, including all sectors, using the time frame of 2021-2030 by targeting the reduction of $115.6 \mathrm{MtCO}_{2} \mathrm{e}(20.8 \%)$ from the waste management; $2 \mathrm{MtCO}_{2} \mathrm{e}(0.3 \%)$ from solid waste management, municipal wastewater management, methane recycling, industrial wastewater management, and other industrial efforts; $0.6 \mathrm{MtCO}_{2} \mathrm{e}(0.1 \%)$ from clinker substitution, refrigerant modification, and other efforts in energy and transportation; 113 $\mathrm{MtCO}_{2} \mathrm{e}(20.4 \%)$ from increasing industrial energy efficiency, enhancing energy efficiency in buildings, internal engine optimisation, using public transport, using biofuel in vehicles, electricity production enhancement, using wind energy, using solar energy, using renewable energy, and increasing household energy efficiency by assigning relevant agencies to take charge (Saiyasitpanich, 2017).

The abovestatementreflects the participation of the Thai government at the international level, which led to the inclusion of the low carbon city policy in the national development plans. This phenomenon demonstrated how significant central policy was in the creations of projects and missions to solve climate change impacts. Through the centrally administrative 
maneuver, many agencies took responsibilities to work on initiatives and the most outstanding one, in this case, was the Ministry of Natural Resources and Environment which carried out projects through its subordinating agencies such as the Green Office Project, the Provincial Greenhouse Gas Reduction Development Project, and the Low Emission Support Scheme (LESS). The ministry requested cooperation for these project operations with various organsations, both in the public and private sectors. In terms of local implementations, the National Municipal League of Thailand also received policy orders from the government to activate local administrative organisations for the problem-solving roles on climate change by launching the Thai Municipality Project towards Low Carbon Cities, a project that gave Hat Yai City Municipality an opportunity to participate in the low carbon operations. Based on the implementations, it could be observed that although national policies are a facilitating factor in the initiations of projects and activities that promoted the reduction of greenhouse gas emissions, the stimulation for cooperation could not be systematically enhanced solely by the responsible bodies for low carbon. This was not to account for the fact that there was no national agency in Thailand that was practically in charge of supervising the local agencies in the low carbon city scheme.

However, the implementation of low carbon cities that begins at the central level was confirmed by academic results as a vital mechanism as this scale of action offers precise goals for low carbon cities. As described by studies, e.g.,Shem et al., (2019), which investigated low carbon cities in Vietnam,the responsible government adopted a low carbon policy as a national policy, tangibly offered supports for renewable energy technologies, private investment mobilisation, and international cooperation, as well as strategically escalated the importance of clean energy operations. Similarly, Zen et al., (2019) reported that since the city of Melaka received guidelines from the central government, it was able to position itself as a preparation city for greenhouse gas adaptability and reduction.
Hence, central policies for low carbon cities are of utmost crucial as they offer a sense of direction for local operations. However, in Thailand, the central government does not yet have any policy that explicitly and legally mandates local operations. Most missions were, thus, conducted through requests for cooperation, where local agencies have the discretion to implement the ideas based on local contexts. Consequently, the missing unified efforts might produce random results beyond anticipation and unlike other low carbon missions that are carried out by other governments with clear mandates on policies, guidelines, and regulations to follow. Therefore, if there are direct rules and regulations, the reduction of greenhouse gas emissions might produce satisfying results in a shorter timeframe.

\section{Local Policies and Plans}

The derived results from relevant documents and interviews reflected that the policies and operations on low carbon cities by Hat Yai City Municipality were implemented without the association with local problems. On the contrary, they emerged from external motivation as the National Municipal League of Thailand operated in accordance with the central policy guidelines with a financial push from the European Union (EU) via the Thai Municipality Project towards Low Carbon Cities. As a result, local administrative bodies (i.e., town and city municipalities) throughout the country were given the opportunity to voluntarily join the project and implement the four strategies for low carbon cities. Subsequently, administrators of Hat Yai City Municipality agreed and approved the participation to adopt the low carbon city scheme as part of its policy for urban environmental development. Specifically, projects and activities were created in the threeyear (2015-2017) and four-year (2017-2021) local development plans. The phenomenon reflected the fact that local policies could be formulated if they are in compliance with national policies and other lawful obligations. Contrarily, they could not be formulated 
if such duties are beyond an authoritative scope. As elaborated by an administrator at Hat Yai City Municipality on a large-scale structural investment policy to reduce city-level greenhouse gas emissions, the implementation was obstructed by bureaucratic difficulties on scopes of duties, e.g., the investment to become a solar energy producer and the investment to transform the urban transportation system. These efforts could not be accomplished as they are beyond existing scopes of duties.

"There are so many things we would like to do, but when we started to do it, we had issues with our scopes of duties. If it is beyond the scope, there is nothing we could do about it. Take the electricity as an example; we are not permitted to become an energy producer because the law says the Electricity Generating Authority of Thailand is the producer. Similarly, a Provincial Waterworks Authority is responsible for water supply. In terms of transportation, a specific unit is also in charge of that. So, we could only do small tasks and implement them within our office. However, we are not in the position to afford significant structural modifications." (An Administrator of Hat Yai City Municipality, interviewed on February 20, 2018)

The interview data reflected that local administrative organsations in Thailand operated under a very limited scope of duties. Hence, although local policies could be issued with administrative approvals and assigned working task forces, only small-scale organisational operations are possible. For instance, in the context of low carbon operations, the best municipalities could do involve small missions such as reduction of energy usage for municipal office buildings, internal garbage separation, or cycling campaigns for officials. The existing practicality is different from other low carbon cities in developed countries where the implementation of policies and working strategies are highly valued. Furthermore, organisational mechanisms are fully employed to plan for the structural changes that lead to necessary decisions for large scale local investments where the public sector could further initiates efforts and coordinate operations with other organisations in networks (Hodson et al., 2013)For example, although low carbon cities in Malaysia were initially implemented and planned at the policy level within organizations, the implementations were made possible by a dedicated government organisation known as Malaysia Green Building Council, whose duties were to support low carbon knowledge and technological development for Malaysian public and private agencies. As a result, buildings and facilities were redesigned and constructed with environmentally friendly solutions to reduce greenhouse gas emissions. (Zen et al., 2019).

Considering the fact that policy formulation and operational planning at the local level depends on the contexts of each city, local administrative organisations in Thailand have not been given proper legal power to handle large-scale projects for its local transformations. This phenomenon is a contrast to many other sovereignties where their local administrative units are equipped with relevant legal authorities to autonomously implement solutions.

\section{Community's Involvement}

Participation in Thai contexts is influenced by fictive kinship where the older ones are respected, and people support each other as a group in a patron-client system and Hat Yai City Municipality was no exception. Since the municipality governs 103 communities and for the convenience in making contacts and coordination, over $80 \%$ of the community leaders were selected based on the existing positive political relationships, fictive-kinship statuses, and social relationships of the leaders. When projects and activities are launched, these community leaders are generally invited to participate with the municipality. They also have an option to inform other community members so that if they are interested, they can voluntarily take part. The same process occurred to the low carbon implementation. Hat Yai City Municipality selected the four communities 
because the community leaders and some of their members were perceived as ready as they have been working on existing low-carbonequivalent activities on a daily basis. However, when considering the results, it was found that the community participation in this study was low as only four communities $(8.28 \%)$ participated only four out of 103 communities $(4.12 \%)$ were involved. Based on Hat Yai City Municipality's report on administrative performance, community participation seems extremely low. However, it was considered as an acceptable start and although the start covered small targets, it was safe to state that the participation already took place in the communities.

In terms of outcomes, despite the partial participation from the leaders and some community members, it was safe to state that a level of participation was present in the communities, and that was made possible because the selected communities had enough social capital to facilitate it. Nonetheless, a disadvantage of this nature of participation is the exclusivity that prevented others in the communities from participating. In addition, there were too many urban residents who did not pay attention to the low carbon activities as they were more interested in careers for economic stability. Also, when some members noticed that their leaders and other community members were already involved with the municipality, they felt that their absences would not impact anything. Nevertheless, they did not clearly express whether they agree or disagree with the strategies being applied to the communities. A community representative stated as follows in the interview:

"I did not know much about it. All I knew was that some people already joined the activities, and it is better for me to go to work and make a living. I was not against it or anything. If they need anything, they can always let me know. It is just that I might not have time." (A community representative, interviewed on April 3, 2019)

This statement reflects that the participation was irrelevant to their needs. Hence, community members spared an effort to participate only to show the society that their responsibilities were justly fulfilled through cooperation. By doing so, they felt that they played their roles without causing trouble, but they had no intention to offer any opinions in regard to the matter. The researcher felt that although Thai social capital encourages an extent of participation, it simultaneously fails to engage everyone across all groups of stakeholders in the city. The problem was that the process lacked the type of communication that stimulates information perception, promotes understanding, and raises awareness among the urban residents to the extent that they felt eager to be part of the urban solutions against greenhouse gas emissions. The case of Hat Yai City Municipality, starting at the community level, can still be considered a promising step towards the success of low carbon cities. Many cities, especially the low carbon communities in developed countries of Europe, started small at the community level and expanded into a network as their community members believed that sharing responsibilities would help them reduce greenhouse gas emissions by $10-20 \%$ (O'Hara, 2013). With such realisation, the implementations became effortless as it was the community members working to fulfill their needs through bottomup initiatives after perceiving that their cities needed to change. As a result, the members began participating in creative and communitydriven projects, including low carbon stores, eco-friendly children centers, renewable power plants, and improved local transport infrastructures.Many cities are pursuing the low-carbon practices to reduce $\mathrm{CO} 2$ and other environmental emissions. However, it is still unclear which aspects a low-carbon city (LCC) covers and how to quantify and certify its low carbon level. In this paper, an indicator framework for the evaluation of LCC was established from the perspectives of Economic, Energy pattern, Social and Living, Carbon and Environment, Urban mobility, Solid waste, and Water. A comprehensive evaluation method was employed for LCC ranking by using the entropy 
weighting factor method. The benchmark values for LCC certification were also identified. The framework was applied to 10 global cities to rank their low-carbon levels. The comparison of cities at different levels of economic, social, and environmental development enhances the holistic of the study. The results showed that Stockholm, Vancouver, and Sydney ranked higher than the benchmark value, indicating these cities achieved a high level of low-carbon development. São Paulo, London, and Mexico City are still in the slow transition towards LCC. Beijing and New York have much lower LCC level than the benchmark value due to the poor environmental performance and infrastructure supports caused by intensive human activities. The proposed indicator system serves as a guideline for the standardisation of LCC and further identifies the key aspects of low-carbon management for different cities (Tan et al., 2017).

When looking into the low carbon communities of Hat Yai City Municipality, it was noted that the agency started the implementation by selecting community participants for low carbon communities and subsequently informed the stakeholders about the threats from climate change. For self-transformations to occur and for members to be able to transfer knowledge to others and inspire further changes, it was important for working agencies to educate them about possible impacts, promote a better understanding, and help them draw connections between causes and effects. However, the researcher believes that such processes could be time-consuming as public agencies local administrative bodies, and other related agencies need to carefully plan the operations, especially the promotion towards understanding, to ensure that community members recognise their roles and personally yearn for self and social changes for city's sustainable and systematic low carbon future.

\section{Implications}

Hence, to answer the questions of "how vital is the low carbon policy is to an implementation of a low carbon city?" and "what strategies could be employed to promote community participation in implementing a low carbon city?" and what influencing factors of a low carbon city implementation are; the results of this study revealed some suggestion of how policies could be linked to participation. It is a low-carbon city participation practice model for Hat Yai City Municipality which was also recommended to other local government agencies. This P-S-P model is as elaborated below.

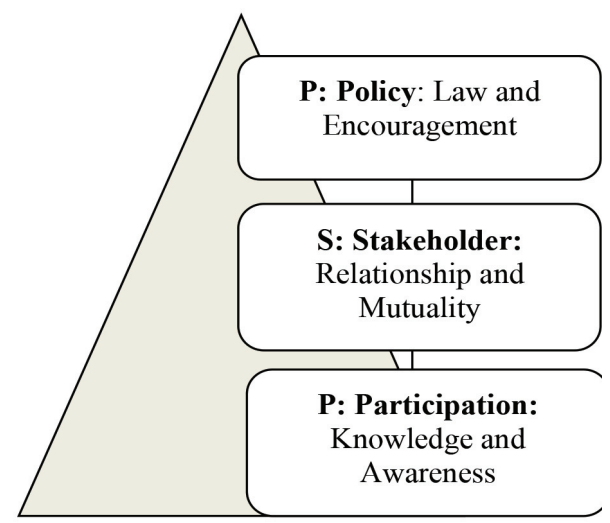

Figure 4: The participation model for low carbon city operations

From the figure above, the participation model for low carbon city operations at national and local agencies comprised three key components: "PSP" with the following details:

$P$ refers to policies that are predetermined by a government agency in either central or local administration under the leadership of an administrator with knowledge of low-carbon cities to address environmental problems, especially to drive low-carbon city operations. These policies should incorporate processes that could tackle problems and promote social, economic, and environmental sustainability. "Laws" should be a vital administrative component of the policies as they can enforce and regulate such management to ensure it could authentically promote the reduction of greenhouse gas emissions and mitigate impacts of climate change. Furthermore, "encouragement" is another component to 
promote all-level operational motivation. Encouragement could be provided through the support of knowledge, finance, technology, and opportunities to participate in low carbon city operations. Finally, policies should be designed with consistency and continuity.

S refers to stakeholders. Stakeholders from all sectors, e.g., public, private, civil society, and public sectors constitute a large number of people in society. Cooperation among stakeholders is fostered to ensure positive relationships at all levels. Operational and relationship mutuality is also supported among stakeholders to ensure mutual benefits. Operations should not be separately carried out and actions should be taken towards the same direction to achieve social productivity.

$\mathrm{P}$ refers to participation. Creating participation in all groups and all levels of stakeholders is vital and stakeholders should be encouraged to acquire problem-related knowledge on environment, climate change, and lowcarbon cities. Education processes should also be developed in response to that. Strategies should be formulated to raise awareness among stakeholders of all sectors until they possess the abilities to think, demonstrate readiness for behavioural transformation (individual and collective levels), and participate in driving urban development towards becoming a "low carbon city."

Hence, for low-carbon city operations to be successful, the three components of the P-S-P model should be developed interdependently. For policies to be successfully put into actions, many factors are relevant, e.g., social foundations, the number of stakeholders from all sectors, and awareness, which are the backbones that drive participation and stimulate policy advocacy. Policies that reflect public needs usually come with a common goal and achievement.

\section{Conclusion}

The low carbon city policy of Hat Yai City Municipality was implemented according to the four strategies for low carbon cities (i.e., City of Trees, City of Waste Minimisation, City of Energy Efficiency, and City of Sustainable Consumption) through organisational mechanisms by assigning bureaus and divisions to take specific responsibilities for internal low carbon missions and the four model communities on low carbon to serve as a social capital towards similar goals. With the help of community leaders and members with perceived potential, community activities were conducted to serve low carbon purposes. As a result, the scheme yielded both quantitative and qualitative outcomes, which reflected the policies of city leaders and community participation. Despite the minimal ratio of household participation and the lower reduction effectiveness of greenhouse gas emissions, the local administrator still considered the phenomenon an auspicious start. Even though the scale of operations was small at this stage, it was perceived to likely expand in the future.

From the results, it could be concluded that the low carbon policy was vital for the low carbon city implementation. However, the central and local governments should formulate policies in a consistent direction, whereas administrators at both levels (i.e., national and local) should show their political will for the implementation and work in collaboration to promote community and stakeholder participation in low carbon cities, as well as attract other communities and sectors to come together to improve the low carbon city. Another essential factor is the information process. Knowledge and understanding should be promoted to raise awareness of low-carbon cities to people at all levels. If low carbon cities could strictly be implemented based on designed developmental strategies and policies, as well as supplemented by necessary participation, accomplishing desirable low carbon goals is not something that is out of reach. Nonetheless, it is hoped that local administrators in the Thai and other developing cities with similar contexts to 
Hat Yai City Municipality would consider these suggestions and apply them in the development for low carbon cities to prevent and mitigate today's threats from climate change.

\section{Acknowledgements}

The authors extend their gratitude to reviewers for critical comments on the manuscript.

\section{Reference:}

Andrews-Speed, P., \& Zhang, S. (2019). China as a Global Clean Energy Champion: Lifting the Veil. Palgrave Macmillan, Singapore. Springer Link. https://doi. org/10.1007/978-981-13-3492-4.

Baeumler, A., Ijjasz-Vasquez, E., \& Mehndiratta, S. (2012). Sustainable low-carbon city development in China. International Development Association or The World Bank. Retrieved July 28, 2020 from

https://www.esmap.org/sites/default/files/ esmap-files/CHINA_Low_carbon_cities_ full_report.pdf.

Bekhet, A. K., \& Zauszniewski, J. A. (2012). Methodological triangulation: An approach to understanding data. Nurse Researcher, 20 (2), 40-43.

Benites-Lazaro, L. L., \& Mello-Théry, N. A. (2019). Empowering communities? Local stakeholders' participation in the Clean Development Mechanism in Latin America. World Development, 114, 254-266.

Bhundej, R. (2015). Thailand's Intended Nationally Determined Contribution (INDC). Office of Natural Resources and Environmental Policy and Planning. Retrieved July 27, 2020 from https:// www4.unfccc.int/sites/ndcstaging/ PublishedDocuments/Thailand\%20First/ Thailand_INDC.pdf.

Birkland, T. B. (2020). An introduction to the policy process: Theories, concepts, and models of public policy making. Library of Congress Cataloging-in-Publication
Data. New York, NY: Rutledge, 2019. 52 Vanderbilt Avenue, New York, NY 10017.

China Urban Sustainability Coalition. (2015). Ten Key Principles of Low Carbon Urbanization Supporting China's New Type of Urbanization. Retrieved December 10, 2019 from https://www.nrdc.org/sites/ default/files/10-key-principles-of-lowcarbon-urbanization-1126.pdf.

Chanjirawuttikul, N. (2012). Leading the way to low carbon society: A paradigm and driving. TRF Policy Brief, 3(20). (In Thai).

Clapp, C., Briner, G., \& Karousakis, K. (2010). Low-emission Development Strategis (LEDS): Technical, institutional and policy lessons. Organisation for Economic Co-Operation and Development. Head of Publications Service, OECD/IEA. Retrieved July 28, 2020 from http://www. oecd.org/env/cc/46553489.pdf.

da Graça Carvalho, M., Bonifacio, M., \& Dechamps, P. (2011). Building a low carbon society. Energy, 36(4), 1842-1847.

de Oliveira, J, A. P. (2019). Intergovernmental relations for environmental governance: Case of solid waste management and climate change in two Malaysian States. Journal of Environmental Management, 233, 481-488.

Eichler, G. M., \& Schwarz, E. J. (2019). What sustainable development goals do social innovations address? A systematic review and content analysis of social innovation literature. Sustainability, 11(2), 522.

Glass, L. M., \& Newig, J. (2019). Governance for achieving the sustainable development goals: How important are participation, policy coherence, reflexivity, adaptation and democratic institutions?. Earth System Governance, 2(April 2019), 100031.

Ho, C, S., Matsuoka., Simsom, \& Gomi. (2013). Low carbon urban development strategy in Malaysia-The case of Iskandar Malaysia development corridor. Habitat International, 37(January 2013), 43-51. 
Hodson, M., Marvin, S., \& Bulkeley, H. (2013). The intermediary organisation of low carbon cities: A comparative analysis of transitions in Greater London and Greater Manchester. Urban Studies.

IPCC. (2014). IPCC Fifth Assessment Report, Climate Change 2014 Synthesis Report Summary for Policy Maker. The final part of the IPCC's Fifth Assessment Report (AR5). Intergovernmental Panel on Climate Change: IPCC.

Isariyanon, M. (2016). Local administrative organization, green economic concept, Muangklaeng sub-district municipality. Journal of Social Development, 18(2), 5775. Retrieved March 6, 2020 from https:// so04.tci-thaijo.org/index.php/jsd/article/ view/70174. (in Thai).

Ismaila, A., \& Bununu, Y. (2019). Low Carbon City. in book: Good health and wellbeing, (pp.1-12). Springer International Publishing.

Jabareen, Y. (2015). City planning deficiencies \& climate change - The situation in developed and developing cities. Geoforum, 63, 40-43.

Johnson, T. M., Alatorr, C., Romo, Z., \& Liu, F. (2009). Low-Carbon Development for Maxico. The International Bank for Reconstruction and Development/The World Bank. Retrieved July 28, 2020 from https://openknowledge.worldbank. org/bitstream/handle/10986/3124/513420 ESW0WHIT1UBLIC10MEDECfinalEng. pdf? sequence $=1 \&$ isAllowed $=y$.

Kersty, H., Jo, H., \& Ruth, M. (2014). Monitoring and evaluation in UK low carbon community groups: Benefits, barriers, and the politics of the local. Local Environment, 21(1), 124-136.

Leal, P, H., \& Marques, A, C. (2019). Are de jure and de facto globalization undermining the environment? Evidence from high and low globalized EU countries. Journal of Environmental Management, 250(2019), 109460.
Levesque, A., Pietzcker, R. C., \& Luderer, G. (2019). Halving energy demand from buildings: The impact of low consumption practices. Technological Forecasting and Social Change, 146, 253-266.

Lou, Y., Jayantha, W. M., Shen, L., Liu, Z., \& Shu, T. (2019). The application of low-carbon city (LCC) indicators-A comparison between academia and practice. Sustainable Cities and Society, 51, 101677.

Mao, Q., Ma, B., Wang, H., \& Bian, Q. (2019). Investigating Policy Instrument Adoption in Low-Carbon City Development: A case study from China. Energies, MDPI, Open Access Journal, 12(18), 1-17.

Mees, H. L. P., Uittenbroek, C. J., Hegger, D. L. T., \& Driessen, P. P. J. (2019). From citizen participation to government participation: An exploration of the roles of local governments in community initiatives for climate change adaptation in the Netherlands. Environmental Policy and Governance, 29(3), 198-208.

Merritt, R. (2015). Cities act on climate: The power of hope. Climate solution accelerating the transition to our clean energy future. Retrieved July 28, 2020 from https://www.climatesolutions.org/series/ lowcarboncities.

Nakano, R., Zusman, E., Nugroho, S. B., Jaeger, A., Janardhanan, N., Muchtar, M., Verma, A., Chaturvedula, S., Kolsepatil, N., Malik, S., \& Tiwari, S. (2017). Low Carbon Governance in Indonesia and India: A comparative analysis with recommendations. Procedia Engineering, 198, 570-588.

Neil, H. (2019). Forum Highlights Low-Carbon Technologies and Policies as Key to Asia and Pacific's Sustainable Future. News Release. The Asian Development Bank (ADB). Retrieved March 6, 2020 from

https://www.adb.org/news/forum-highlightslow-carbon-technologies-and-policies-keyasia-and-pacifics-sustainable-future. 
Nuzir, F. A., \& Dewancker, B. J. (2014). From Sustainable to Low Carbon City: Zero Emission Urban Mobility in Japanese Cities. Conference: 11th International Conference of Asia Institute of Urban Environment, At Daegu, Republic of Korea. Retrieved July 10, 2019 from https://www. researchgate.net/publication/268507874 From_Sustainable_to_Low_Carbon_City_ Zero_Emission_Urban_Mobility_in_ Japanese_Cities.

O'Hara, E. (2013). Europe in Transition Local Communities Leading the Way to a LowCarbon Society. AEIDL, the European Association for Information on Local Development. Retrieved July 28, 2020 from https://www.aeidl.eu/images/stories/pdf/ transition-final.pdf.

Opschoor, J. B., \& Pearce, D. W. (Eds.). (1991). Persistent pollutants: Economics and policy. Dordrecht: Kluwer Academic Publishers.

Peng, W., Wang, X., \& Guo, L. (2018). An Exploration of Neighborhood Residents' Cognition of and Participation in LowCarbon Behaviors in Wuhan, China [Research Article]. Advances in Civil Engineering; Hindawi. https://doi. org/10.1155/2018/8764801.

Peng, W, J., Wang, X, M., Zhao, G, C., \& Wang, X. (2018). An investigation into neighborhood residents' cognition of and participation in low-carbon behavior a case study in Chengyan district of Qingdao, China. International Journal of Sustainable Development and Planning, 13(5), 818837.

Persson, A., \& Sjöstedt, M. (2012). Responsive and responsible leaders: A matter of political will? Perspectives on Politics, 10(3), 617-632.

Phap, V. M., Huong, T. T., Hanh, P. T., Duy., \& Binh, D. V. (2020). Assessment of rooftop solar power technical potential in Hanoi city, Vietnam. Journal of Building Engineering, 32(November 2020), 101528.
Pichitthanarat, N. (2015). The concept of local power structures analysis in Thailand. Burapha Journal of Political Economy, 3(2) July - December 2015. Retrieved July 28, 2020 from https://so01.tci-thaijo.org/ index.php/pegbuu/article/view/199456 (in Thai).

Ramaswami, A., Main, D., Bernard, M., Chavez, A., Davis, A., Thomas, G., \& Schnoor, K. (2014). Planning for lowcarbon communities in US cities: A participatory process model between academic institutions, local governments and communities in Colorado. Carbon Management, 2(4), 397-411.

Roberts, C., Geels, F. W., Lockwood, M., Newell, P., Schmitz, H., Turnheim, B., \& Jordan, A. (2018). The politics of accelerating lowcarbon transitions: Towards a new research agenda. Energy Research \& Social Science, 44, 304-311.

Saiyasitpanich, P. (2017). Achieving Thailand's Nationally Determined Contributions: National Perspective. "APN, LoCARNet and AIT/RRC.AP Capacity Building Workshop and Science-Policy Dialogue on Low Carbon Development" 6 February 2017. Retrieved July 28, 2020 from from www.apn-gcr.org.

Shem, C., Simsek, Y., Hutfilter, U. F., \& Urmee, T. (2019). Potentials and opportunities for low carbon energy transition in Vietnam: A policy analysis. Energy Policy, 134, 110818.

Sothea, K., \& Oanh, T, K. (2019). Characterization of emissions from diesel backup backup generatiors in Combodia. Atmospheric Pollution Research, 10( 2), 345-354.

Tan, S., Yang, J., Yan, J., Lee, C., Hashim, H., \& Chen, B. (2017). A holistic low carbon city indicator framework for sustainable development. Applied Energy, 185, 19191930. 
Thailand Environment Institute. (2011). Hat Yai City Climate Resilient Strategies. Asian Cities Climate Change Resilience NetworkACCCRN. Retrieved July 28, 2020 from http://hatyaicityclimate.org/upload/forum/ ResilienceStrategyofHY-Thai.pdf (in Thai).

Thailand Greenhouse Gas Management Organization (Public Organization). (2019). Thailand Synergized with China and ASEAN Countries on Renewable Energy Transition to Encounter Climate Change and Reduce Greenhouse Gas Emission. Published Date 2019-10-08. Retrieved July 28, 2020 from http://www.tgo.or.th/2015/ english/events_detail.php?id=445.

Thaisaereenews. (2019). Public Consultation: LRT Khon Kaen. Retrieved March 6, 2020. Retrieved July 28, 2020 from https://www. thaisaeree.news/14286/ (in Thai).

Thomas, I. (2007). Environmental Policy. The Federation Press, National Library of Australia.

Tosun, C. (1999). Towards a typology of community participation in Tourism Development Process. Journal Tourism and Hospitality Research, 10(2), 113-134.

Wijaya, S., Imran, M., \& McNeill, J. (2017). Multi-level policy tensions in Bus Rapid Transit (BRT) development in low-income Asian cities. Transportation Research Procedia, 25, 5104-5120.

World Bank; DNV KEMA. (2014). The Low Carbon City Development Program
Guidebook : A Systems Approach to Low Carbon Development in Cities. World Bank, Washington, DC. (C) World Bank. Retrieved July 17, 2019 from https://openknowledge. worldbank.org/handle/10986/21731 License: CC BY 3.0 IGO."

UN Web TV. (2015). Thailand, General Debate, $70^{\text {th }}$ Session. Retrieved July 30， 2020 from http://webtv.un.org/watch/thailandgeneral-debate-70th-session/45193006560 01 ? page $=3$ ?lan $=$ english .

van der Heijden, J. (2016). The New Governance for Low-Carbon Buildings: Mapping, Exploring, Interrogating (March 29, 2016). RegNet Research Paper No. 2016/106, Retrieved July 28, 2020 from https://ssrn. com/abstract=2755876 or http://dx.doi. org/10.2139/ssrn.2755876.

Xing, L., Li, G., Pongpiachan, S., \& Wang, Q. (2020). Quantifying the contributions of local emissions and regional transport to elemental carbon in Thailand. Environmental Pollution, 261, 114272.

Yusup, G, S, B., Melda, R, J., \& Maman, I, Li, J. (2020). Sustainable Low Carbon Urban Lighting Analysis: A case study of Bandung City. Journal of Engineering Sciences, 7(1), H9-H18.

Zen, I. S., Al-Amin, A. Q., \& Doberstein, B. (2019). Mainstreaming climate adaptation and mitigation policy: Towards multi-level climate governance in Melaka, Malaysia. Urban Climate, 30, 100501. 